Document downloaded from:

http://hdl.handle.net/10251/177472

This paper must be cited as:

Calvo Roselló, V.; Capilla Tamborero, E.; Navarro Fajardo, JC. (2020). Oval Domes. The Case of the Basílica de la Virgen de los Desamparados of Valencia. Nexus Network Journal. 22(2):393-409. https://doi.org/10.1007/s00004-019-00465-0

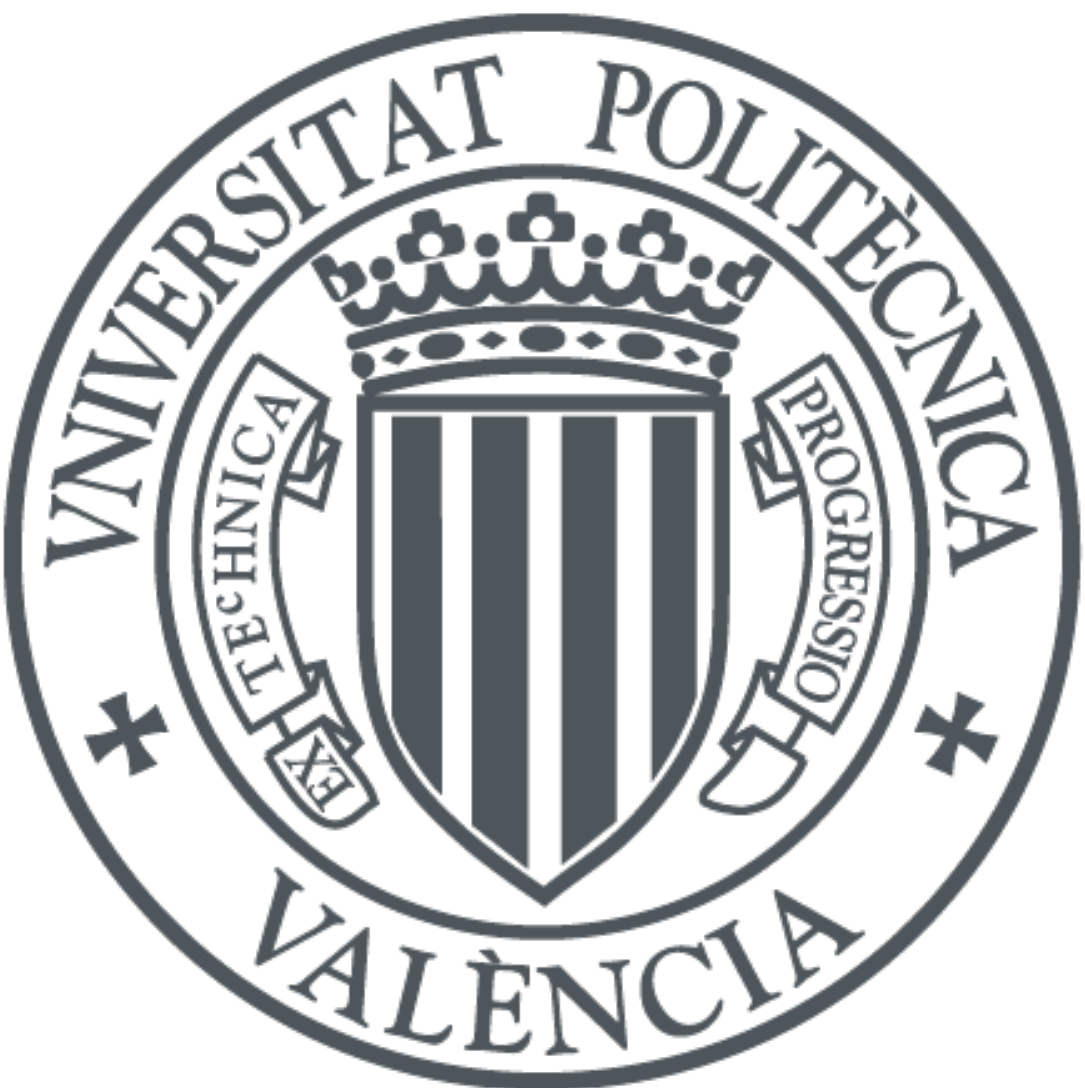

The final publication is available at

https://doi.org/10.1007/s00004-019-00465-0

Copyright Springer-Verlag

Additional Information 


\title{
Oval domes. The case of the Basilica de la Virgen de los Desamparados of Valencia
}

Received: date / Accepted: date

\begin{abstract}
The dome of the Basilica de la Virgen de los Desamparados of Valencia is an emblematic example of Valencian baroque architecture and painting. Its shape, oval or elliptical, has been the subject of controversy in various studies. The study of oval domes throughout history is a very interesting field of research because, among other things, the determination of the exact shape is important in order to conclude how it was built.

We approach the problem from a new mathematical point of view, calculating the distances between the points that make up the real data cloud and the hypothetical form considered, oval or ellipse. The use of modern graphic surveying techniques, carried out with a 3D laser scanner, and computation with the powerful symbolic and numerical mathematical solver, Mathematica, has allowed us to accurately determine the shape of the dome and determine that its sections are not well-described by ellipses. A better fit is obtained assuming that sections are ovals. The programming and generalization of the mathematical method employed in this work will allow it to be applied to determine the exact geometry of other oval or ellipsoidal vaults.
\end{abstract}

Keywords Oval form · Mathematica software - Oval domes · Basílica de la Virgen de los Desamparados

\section{Introduction}

The interior dome of the Basilica de la Virgen de los Desamparados of Valencia, constitutes an emblematic element of the Valencian baroque architecture. This temple is also the most popular and representative Marian devotion centre of Valencia, declared a Historical Monument in 1981 (R.D. 5-6-1981 B.O.E. 10-8-1981). It is "the first oval plan that is made in Valencia for a religious 
temple" (Bérchez 1995: 206). The interior dome, decorated in 1701 by Antonio Palomino with frescoes, constitutes a jewel of baroque mural painting in Spain.

The Real Capilla de la Virgen de los Desamparados, designated as a Basilica in 1872, was constructed between 1652 and 1667, under the direction of Diego Martínez Ponce de Urrana. However, in the Capitulations and conditions for the construction of the Chapel signed on November 19, 1653, Diego Martínez himself and José Montero and José Artigues (Montoliu 2012: 29-31) appear as the executors.

The dome actually consists of two domes: an outer, resistant dome, built between 1661 and 1665, and another interior, not as resistant, built in 1701, which conceals the intrados of the first and constituted the basis for the frescoed pictorial decoration by Palomino (Fig. 1). The major axis of the outer dome measures $18.90 \mathrm{~m}$; its minor axis, $15 \mathrm{~m}$, and its height is $12.70 \mathrm{~m}$. It is formed by a continuous sheet of $31 \mathrm{~cm}$ thick and reinforced by eight meridian ribs of $45 \mathrm{~cm}$ of cross-sectional width (Bosch et al. 1999: 54-55). The inner dome is partitioned, constituting one of the most leanly constructed domes that have ever been built (Huerta 2012: 318). It is formed by "two threads of solid ceramic brick of a thickness of $3.5 \mathrm{~cm}$ for the intrados and $2.5 \mathrm{~cm}$ for the extrados, taken and coated with mortar of plaster, anchored to the original dome and strengthened by 127 forged metal rods" (Bosch et al. 1999: 54-55 and 2001).

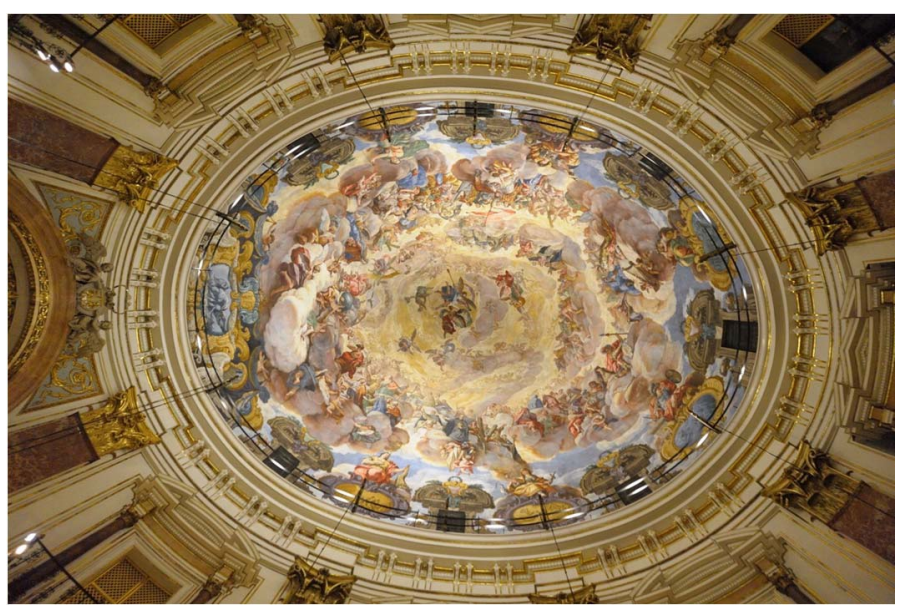

Fig. 1 Interior dome

The present paper is based on a previous study on the spatial geometry of the interior dome of the Basilica. This study is included in chapter 8 of the book, "Bóvedas valencianas. Arquitecturas ideales, reales y virtuales en época medieval y moderna", entitled "La cúpula interior de la basílica de la Virgen 
de los Desamparados de Valencia. Análisis geométrico y matemático" (Capilla and Calvo 2014). In this publication the hypothesis is that the dome is oval and not ellipsoidal, as some authors say. The results that we have obtained in this article reinforce that hypothesis.

The description of the dome is simplified by describing it using a set of horizontal planes that intersect the dome. The problem that arises is to calculate the geometric form of the curves that best approximate the points that describe the intersection of these planes with the dome. Obviously, among the infinite possible geometric forms, we must limit the problem and start from that or those which are the most plausible, in our case the oval and the ellipse. At first glance it is almost impossible to distinguish from the curve if it is one or the other. However the exact determination of the curve type is important because they are architecturally constructed in a totally different way. Therefore the analysis of its form will also allow us to know how it was constructed.

\section{Historical background}

The oval shape and the methods for constructing it have also been the object of many ancient treatises and studies (Serlio 1552, Arphe 1585, Navascues 1974). The dome we are dealing with is generated by ovals, as we have already mentioned, so we consider necessary to refer to other domes built with this type of geometry in different countries and historical periods. There are numerous studies on the geometry of spaces built by ellipses or ovals, either in horizontal or in vertical section. Among them we will mention, in Spain, Gentil (1994, 1996), Soler Verdú (1995), Fernández (1996), Huerta (2002, 2007), García Jara (2008), López Mozo (2011), Capilla and Calvo (2014), Gómez-Collado et al. (2018); from other countries, Ragazzo (1995), Dotto (2001), Simona (2005), Hatch (2015), Mazzoti (2014a, 2014b, 2017).

It is well known that throughout history there has been some confusion in the use of the terms oval or ellipse. Geometries built with both, ellipses and ovals, frequently has been referenced with the generic term ovals. As Gentil (1996:83) mentions, the use of the terms oval and ellipse as synonyms has been usually applied by critics but also by authors who, knowing the differences, used them consciously, such as René Descartes or Alberto Durero. Therefore, in this section, we are going to refer to both geometries indistinctly, as they are collected by the authors who mention them.

We begin this route in the middle of the sixteenth century and first of the seventeenth, period in which many domes were built. As García Jara (2008:24) collects, "A characteristic type of plan emerged from Vignola's hand: the longitudinal elliptical which represents the synthesis of longitudinality and centralization and therefore satisfies the fundamental aspirations of the time, although it poses the technical difficulty of building large domes on elliptical spaces" (own translation). Vignola (1507-1573) built the first church with an oval dome (Huerta 2007:231-232), Sant'Andrea in Via Flaminia in Rome 
(1550-1554) and in 1547 he designed the first bridge with oval arches, something that became widespread at the beginning of the 18th century. Another of his churches, Santa Maria dei Palafrenieri (1565-1572), also have an oval dome arranged over space, likewise, oval. Disciples of Vignola, like Volterra and Vitozzi also designed churches with domes of oval geometry: the first, San Giacomo degli Incurabili (1590), in Rome, and the second, the Sanctuary of Vicoforte (1595), in Piemonte.

Fundamental figure in the use of oval geometry was Francesco Borromini (1599-1667), who also had a great influence on other architects. As Soler Verdú (1995: 12) collects, his plans "are highly complex, generally develop elliptical geometries". Among his works made with this type of geometry, it is worth highlighting the dome of the church of the convent of San Carlo alle Quattro Fontane, Rome, (1638-1641). We can find several works that study its geometry as Connors (1999), Simona (2005), Hill (2013), Mazzoti (2014a, 2017), Duvernoy (2015) or Petrovic (2019), among others.

Another Italian figure relevant to the use of oval forms is Bernini, who was commissioned to carry out in Rome the project of the church of Sant'Andrea al Quirinal (1658-1670). For its construction, as Jung (1997:30) describes, he chose as form "neither the circle, (...) nor the Greek cross, (...) but the oval, already used in the project of the St. Peter's Square" (own translation).

Fundamental is also Guarino Guarini (1624-1683), whose work reflects the influence of Borromini. Rafael Soler (1995:13) highlights the use made of the constructive resource "la volte a fascie", consisting of "compartmentalizing, in bands by means of arches, the space to be covered with vaults" and the structures are "of great conceptual complexity (...) and the constructive technique that allows to make such complex constructions, is based on the use of the brick factory", a technique that related to the one used in the Valencian domes.

In France it is worth noting the dome, of oval geometry, of the church of the College des Quatre Nations, Paris, (1662-1672) built by the architect Louis Le Vau. He conceived the main front, which overlooks the Seine, with concave wings frame the centralized oval interior building, in the line of the Roman Baroque (Borngässer 1997b: 129).

In Austria it must be highlighted the proposals of Johan Bernhard Fischer von Erlach (1656-1723); among them, it is necessary to mention the church of St. Charles Borromeo in Vienna (1716-1737), whose high-drum dome is "the centre of his reflections" and in which he places the oval in the "core of composition" (Kluckert 1997: 249). Also the Caesarean Library of Vienna (1723-1725), built by his son Joseph Emanuel, is a central oval dome in the middle of the barrel vault of the library (López Manzanares 2005). Its longitudinal section is a semicircle and the cross section is semi-oval (Huerta 2007: 238).

In Spain it is necessary to mention the dome of the church, with an oval interior space, of the Cistercian convent of Las Bernardas in Alcalá de Henares, begun in 1617 and built by Sebastián de la Plaza. It is the only oval building with a dome that is conserved from its time and that moves away "from the 
rigorous classicism of the Herrera school" (Borngässer, 1997a: 85). In Murcia we find the dome of the Chapel of the Transfiguration of the Cathedral of Murcia, (ca 1545), by Jerónimo Quijano. It is a "very early ellipsoidal vault." (García Jara 2008: 188). Calvo et al.(2005: 212) say that the intrados of the vault is a scalene ellipsoid, in which the arrow of the vault is different from the length of each of the semi-axes The authors describe that "the frieze is elliptical and the vault, ellipsoidal, initiating a tradition of elliptical tracings against an Italian tradition of oval tracings" (own translation).

Also in Spain, it is worth highlighting the oval dome of the Chapter Hall of the Cathedral of Seville (1558-1592) by Hernán Ruiz el Joven. In the analysis of its geometry from the photogrammetric survey, Gentil (1996) confirmed the use of ellipses.

On Valencian domes, Soler Verdú (1995) deals with the study of the dome in modern Valencian architecture from the sixteenth to the eighteenth centuries, making an approximation "to the architectural fact of the covering of buildings by using domes in the territory subject to the influence of the city of Valencia, from its origins, in the second half of the 16th century, until the end of the 18th century". He studied in greater depth the most representative domes of the city of Valencia; among them he refers to the oval geometry of the neoclassical Chapel of the Third Order of the old convent of Carmen, by the architect Vicente Gascó, and to the dome of the Basilica de la Virgen de los Desamparados, built at the end of the 17th century, on which, in 1701, another interior is built, not resistant, that hides the first one; it is the latter that we refer to in this article.

\section{Mathematical study of the dome}

In the work of Capilla and Calvo (2014) this dichotomy between oval and elliptical construction throughout history, relating it to the dome of the Basilica de la Virgen de los Desamparados of Valencia, is analyzed. The starting point of that study is a graphic survey conducted with a 3D laser scanner (Fig. 2) with which it is possible to obtain a cloud of more than five million points. In order to manage the data, the cloud is refined, in a random way, to reduce the number of points to just over 50.000. The hypothesis that is pointed out, through an exhaustive graphic study, is that the dome is not made of ellipses, as has been mostly affirmed (Montoliu 2012, Bosch 1999), but was built with oval shapes. Huerta (2002) already mentions that the base of the dome and the drum are ovals.

In the present paper we develop, improve, and extend this mathematical study in the horizontal planes describing the entire dome. We have obtained more precision using a cloud of more than 300.000 points and, in addition, with a new mathematic point of view. Addressing the problem from this new approach has meant work using the powerful computers of our University's Computing Centre. Many of the calculations we have had to make have been made by means of large loops that diversified these calculations among several 


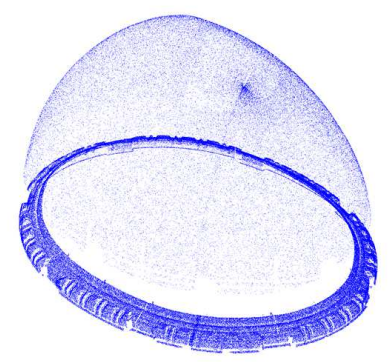

Fig. 2 Cloud obtained with the 3D laser scanner

computers; this has allowed us to reduce the waiting time in performing computations to a few hours. Thus, we have also been able to calculate distances, in each plane, to find the ellipse that best describes the data. The results obtained consolidate and reinforce the hypothesis that the dome is built with ovals and not ellipses.

\subsection{Construction of ellipses}

The process we have followed is to work by defining the set of ovals or ellipses as being the boundary of a set of horizontal planes intersecting with the dome to determine in each case the geometric curve that best approximates the boundary for a particular plane. The boundary itself is identified by nearby points defined by the scanner.

We took horizontal sections by grouping the data into $6 \mathrm{~cm}$ high sets. The height of the top of the dome from the bottom (cornice) is $11.5 \mathrm{~m}$. The overhanging cornice prevents us from obtaining data in the stringer plane (located at the bottom of the dome), so the first plane for which we have data is located at a height of $1.83 \mathrm{~m}$ above the stringer plane. Dividing the difference of heights by $0.06 \mathrm{~m}$ we obtain a total of 162 planes, each with an associated ellipse or oval, and each associated with a set or group of data. The upper region of the dome flattens out, so in this area we refine the distance between planes by a factor of 2 , with a separation of $0.03 \mathrm{~m}$, beginning at about $9.3 \mathrm{~m}$ above the cornice (from our group 125). Consequently, we ended up with 199 groups or data sets each defining an oval or ellipse.

The first job is to centre the data. It should be noted that the centre of the dome is not a perfectly determined physical point, but its central axis is a hypothetical straight vertical line in the air.

The points of the data set cloud are given by three coordinates $(X, Y, Z)$ with respect to a coordinate system of arbitrary origin, in which $Z$ represents the height. We need to determine the point $\left(X_{0}, Y_{0}, Z_{0}\right)$ which is the centre of the dome in the plane corresponding to the top of the cornice $(11.5 \mathrm{~m}$ below the ceiling) and the set of axes $O X$ and $O Y$ correspond to the semi-axes of 
the hypothetical ellipses that are formed in each horizontal plane within the dome. From the centre point, we obtain the new coordinates $(x, y, z)$, in the new translated coordinate system, by the formula

$$
x=X-X_{0}, \quad y=Y-Y_{0}, \quad z=Z-Z_{0}
$$

The maximum value of $Z$ in the points of the cloud is $25.49 \mathrm{~m}$ (the distance from the floor of the Basilica), so the determination of $Z_{0}$ is immediate: $Z_{0}=$ $25.49-11.5=13.99$. With these values our first horizontal data plane is placed $1.83 \mathrm{~m}$ above the hypothetical plane containing the point $\left(X_{0}, Y_{0}, Z_{0}\right)$ at the bottom of the dome.

We now describe the determination of the point $\left(X_{0}, Y_{0}\right)$ in an arbitrary plane. In each row, at a given height $z$, the points of the data set at that height are $\left(X_{i}, Y_{i}\right)$, with $i=1,2, \ldots, n$ with $n$ being the number of points in the plane. The length of the semi-axis $a$ along the axis $O X$ will be the half of the maximum distance between the values $X_{i}$ of all the points. As the data corresponding to each plane is not rotated, this is calculated by:

$$
a=\left(\max \left\{X_{i}, i=1,2, \ldots, n\right\}-\min \left\{X_{i}, i=1,2, \ldots, n\right\}\right) / 2 .
$$

And the same with the length $b$ of the other semi-axis, along the $O Y$ axis:

$$
b=\left(\max \left\{Y_{i}, i=1,2, \ldots, n\right\}-\min \left\{Y_{i}, i=1,2, \ldots, n\right\}\right) / 2 .
$$

Thus, the centre of the points for this plane is calculated by:

$$
\begin{gathered}
X_{0}=\max \left\{X_{i}, i=1,2, \ldots, n\right\}-a \\
Y_{0}=\max \left\{Y_{i}, i=1,2, \ldots, n\right\}-b
\end{gathered}
$$

If the construction were perfect, this point $\left(X_{0}, Y_{0}\right)$ would be the same in all the planes. Obviously, the small imperfections in the way the dome was built and those that could have been produced with the passing of the years produce variations for each plane. However the differences are surprisingly small, no more than 3 or $4 \mathrm{~cm}$, which gives us confidence not only of the reliability of the data with which we work, but also the enormous precision that the masters of the time achieved when they built the dome. The average of the values of $X_{0}, Y_{0}$ in all the planes, up to a height of approximately $9.30 \mathrm{~m}$, is $X_{0}=-2.06, Y_{0}=0.46$ with very minor data dispersion. From the height of $9.30 \mathrm{~m}$ from the base up to the top of the dome, we observe that the centres move slightly as a function of the height (up to about $4-5 \mathrm{~cm}$ in each axis). We have done the calculations taking this into consideration and have compared them with those obtained without displacing the centres, and although the differences we have obtained are small, they confirm that displacement of the centres as we gain height. What we have done is to take the average of all the obtained centres as the real centre of the dome and this was taken as our point $\left(X_{0}, Y_{0}\right)$. Our new translated points are

$$
\left(x_{i}, y_{i}, z_{i}\right)=\left(X_{i}-X_{0}, Y_{i}-Y_{0}, Z_{i}-Z_{0}\right) .
$$


The new data centered in each plane at a height $z$ corresponding to the group $g$ we have called elz. Sorting the points from lowest to highest height in the corresponding excel file to take data from Mathematica, if $n_{g}$ is the row in which the data of the group $g$ begins:

$$
e l z=\left\{\left(x_{i}, y_{i}\right), i=n_{g}, n_{g}+1, n_{g}+2, \ldots, n_{g+1}-1\right\}
$$

When looking for the ellipse that best approximates the data it appears that one way to do this is by using the least squares method to minimize the squared sum of the distance between the proposed ellipse and each point in the corresponding plane. However, we have two problems with this method. The first is to clearly define what we intend when we look for the ellipse that best approximate the data. Actually, what we are looking for is an ellipse in which the maximum value of the distances $d$ from each data point to the ellipse is the smallest possible. However using the method of the least squares this is not what we would obtain. What is calculated with this method is the smallest mean square error of the differences $D$ between the values of $y_{i}$ for each $x_{i}$. Fig. 3 shows what we mean by this.

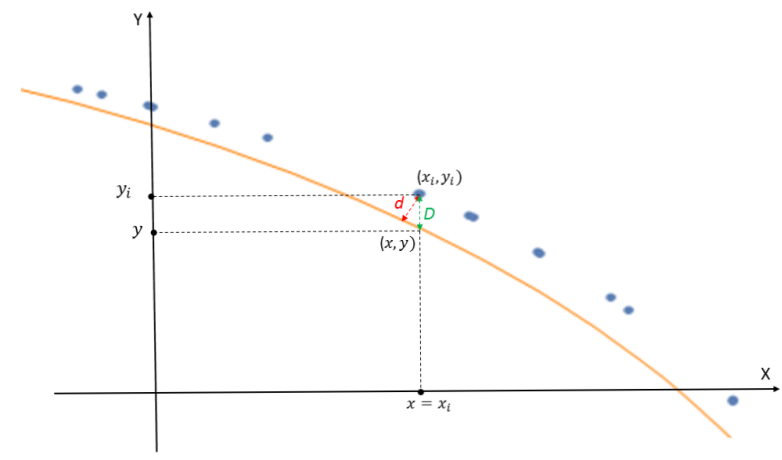

Fig. 3 Two distance calculation modes

If $(x, y)$ are the points of an ellipse of semi-axes $a$ and $b$ then they satisfy the equation

$$
\frac{x^{2}}{a^{2}}+\frac{y^{2}}{b^{2}}=1
$$

Minimizing the mean square error is to calculate the values of $a$ and $b$ that minimize the function

$$
F(a, b)=\sum_{i}\left(y_{i}-b \sqrt{1-\frac{x^{2}}{a^{2}}}\right)^{2}
$$

The difficulty of this calculation makes linearization of the problem necessary. So what we actually calculate with the least squares method are the 
values of $a$ and $b$ that minimize the function

$$
G(a, b)=\sum_{i}\left(y_{i}^{2}-b^{2}\left(1-\frac{x^{2}}{a^{2}}\right)\right)^{2}
$$

The ellipse thus obtained is not necessarily the one that best approximates the data, but it is the best that can be found analytically and generically. In any case, because the data are close to the form sought (which is our case) the solution that is obtained by this method is very good.

We have calculated all the distances $d$ (Fig. 3) between each point of the real data and the ellipse defined above, using Mathematica software. It is clear that these numeric distances are greater in specific points where constructive deformities are present, and for this reason, these points have not been considered because, evidently, they do not define the shape of the corresponding curve. In that points with deformities, sudden changes appear in the values of the distance obtained, but in the normal points the distances presented gradually increase, which shows that the shape of the curve considered is not a good fit to the data.

A table with all the distances from the data points to the ellipse in each plane is shown in the annex attached to this paper. Looking at this table, we can see significant distances between the ellipses of each plane and the data.

But these ellipses could not really be improved with a larger data set, as we have said already. What is needed is take distances to "all" the ellipses close to data, and then see which one is the one that best approximates the data in each plane, which is impossible, obviously. But what we can do is to test a set of ellipses by increasing centimeter by centimeter the semi-axes. We were able to do this using programming and computation with Mathematica, and then, computing the distances of each of these ellipses from the data.

To be exact, we calculate the distances $d$ of the data to any of the ellipses

$$
\frac{x^{2}}{(a+0.01 i)^{2}}+\frac{y^{2}}{(b+0.01 j)^{2}}=1, \quad \text { with } \quad i, j=0,1,2, \ldots, 18
$$

We increase the length of the ellipse semi-axes until we observe that the distance to the data $d$ exceeds $18 \mathrm{~cm}$. It is not necessary to take larger values for the semi-axes, $i, j$ because, as we will see in the next subsection, the ovals produce a maximum distance of less than $18 \mathrm{~cm}$ in all data planes, thus, ellipses with greater semi-axes are not of interest to us. In addition, we have also shown, graphically, that the ellipse is always inside the curve defined by the data, so it is not necessary to consider ellipses with smaller semi-axes once the ellipse is circumscribed by the data, that is, negative values of $i, j$ (an exception is from group 180 upwards, where the shape of the dome becomes more irregular in the proximity to the zenith; here we have considered negative values of $i$ and $j$ ). There is no point, therefore, in considering a greater range of variation for the values of $i, j$. We also have to take into account that this range of values implies that for each group we must calculate distances with $19 \times 19=361$ different ellipses. This calculation involves several hours of computation and 
large memory needs in each group (many groups have more than 3000 points) and it is more than sufficient for our purposes, to not consider a larger range. Again, it is important to emphasize that these calculations have been possible by using the powerful computers in the Computing Center of the Universitat Politècnica de València,

In this way, for each plane, we have calculated the values of $i, j$ for which the corresponding ellipse is closest to the data. These values are shown in the annex to this paper.

Obviously this set of ellipses better approximate the shape of the dome than either the set of ellipses with semi-axes $a$ and $b$ set as constants and obtained directly from the data, or the ellipses obtained by applying the least squares method, but it still seems to not approximate the data as well as they could. It can be seen in the annex that these ellipses are separated from the data, in almost all the planes, a distance of up to $13-17 \mathrm{~cm}$.

\subsection{Approximation by ovals}

Another possible shape is the oval. But there are infinite ways of generating an oval. Throughout history many authors have studied the use of the oval in architecture. The books by Serlio (1552) have served as the basis for all subsequent development. More recently several authors have approached the construction of ovals and oval arches in architecture and engineering, both from a graphical and mathematical point of view (Barrallo 2011, Capilla and Calvo 2014, García Jara 2010, Gómez-Collado et al. 2017, Gentil 1996, López Mozo 2011, Rosin 2001).

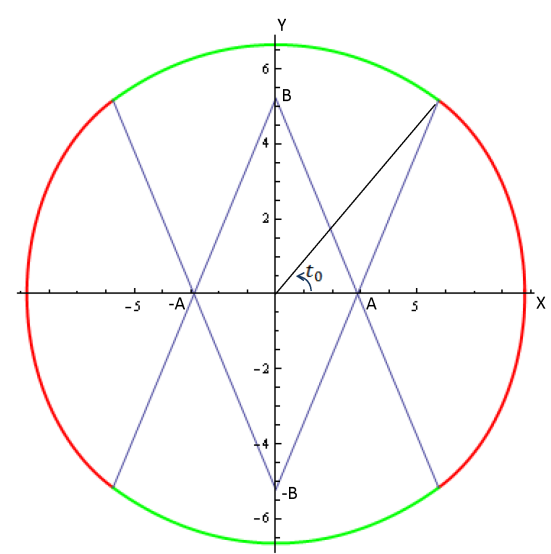

Fig. 4 Construction of ovals 
An oval is formed by taking segments from four circles centered on the points, $(A, 0),(-A, 0),(0, B)$ and $(0,-B)$, on the coordinate axes, and minor and major radios, $r$ and $R$, respectively. The equations of these circles are:

$$
\begin{gathered}
(x-A)^{2}+y^{2}=r^{2} \\
(x+A)^{2}+y^{2}=r^{2} \\
x^{2}+(y-B)^{2}=R^{2} \\
x^{2}+(y+B)^{2}=R^{2}
\end{gathered}
$$

The oval is described by the above equations, where the values of $x$, and $y$ determine the relevant circular equation by computing the angle

$$
\theta=\arctan (y / x \text {. })
$$

Determination of $\theta$ determines the circular equation used to compute the position of point $(x, y)$ making up the oval as shown in Fig. 4.

In order for these circumferences to form the oval, they are cut and are tangent in four points so that the angle $\varphi$ of its polar coordinates is $t_{0}, \pi-$ $t_{0}, \pi+t_{0}$ and $2 \pi-t_{0}$, being

$$
t_{0}=\arctan (r B / R A)
$$

Imposing conditions on the centres, the radii and the corresponding semiaxes $a$ and $b$, the various construction possibilities are obtained.

Among the infinite possibilities, the construction hypothesis that is obtained in Capilla and Calvo (2014) is based on the condition $B=3 A$. If this condition is applied, you get

$$
A=\frac{1}{6}(4+\sqrt{10})(a-b)=1,1937129(a-b)
$$

An example of the fit of this oval to the data may be seen in Fig. 5, an interactive graphic by Mathematica, made with the data of group 58. The precision of the approach is observed in that figure.

To take distances $d$ (Fig. 3) between this oval shape and the data, we need to do the same as in the ellipse. But now, the data must be grouped in four subsets that correspond with each of the four circumferences that form the hypothetical oval that is being sought. In each plane, the value of $t_{0}$ is obtained with the conditions that correspond to it, and the points $\left(x_{i}, y_{i}\right)$ are of one or another subset according to the sign of its coordinates and to whether the value of the ratio $y_{i} / x_{i}$ is more or less than $t_{0}$. This division of the points in each plane in the four subsets is necessary because when distances are calculated between the model and the real data, they must be taken from each point with respect to the corresponding circumference (of the four that form the oval) according to its position on the hypothetical oval. In the Figures 6 and 7 it can be seen the difference between the oval shape so drawn (green) and the ellipse (magenta) which is the one that best approximates the real data. 


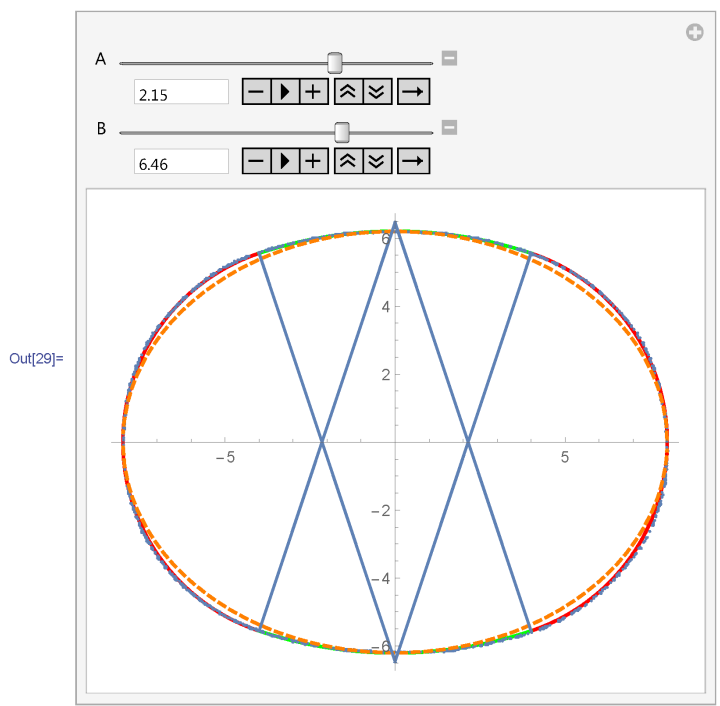

Fig. 5 Blue: real data. Green and red: oval constructed with the previous condition where for data group 58. In this case $\mathrm{A}=2.15$ and $\mathrm{B}=6.46$. Dashed line is the data from group 58 . Orange: ellipse
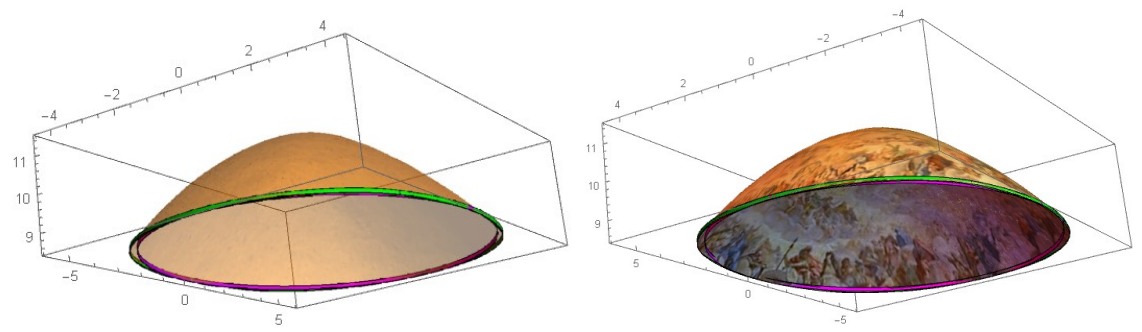

Fig. 6 Difference between the oval an the ellipse at group 112. Standard view

This graph corresponds, as an example, to the group 112, at a height of $8.5 \mathrm{~m}$ from the bottom of the dome. It is easy to see that the oval approach is better than the elliptical one.

With this hypothesis on the construction of the ovals we have obtained distances between the oval and real data and these ones improve considerably the ones we have calculated with the ellipses, as can be seen in the annex.

\section{Results and conclusions}

The comparisons we have made between the oval thus constructed and the ellipse that best approximate the cloud of points obtained in this work confirm 

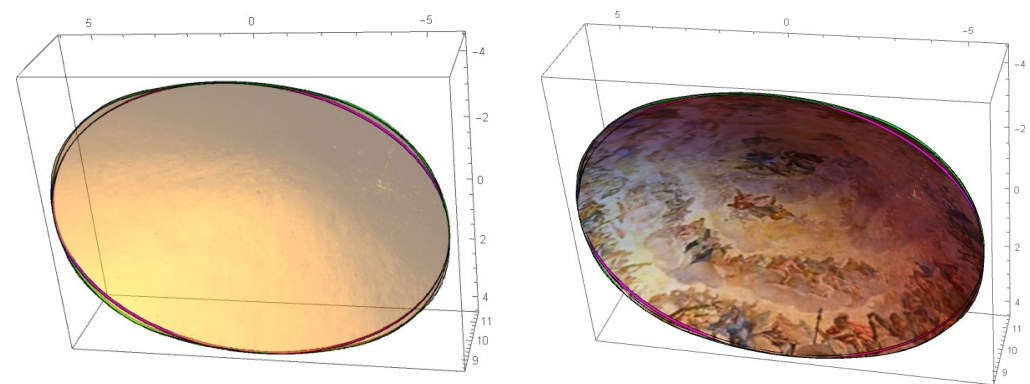

Fig. 7 Difference between the oval an the ellipse at group 112. Bottom view

that the oval shape is the most faithful to the real data. A table with all the obtained values is attached, as we have already said, as an annex to this work.

Range of variation of the maximum separation (in $\mathrm{cm}$ ) with the data:

Minimum: minimum value of the maximum distances of the corresponding curve with the real data

Maximum: maximum value of the maximum distances of the corresponding curve with the real dato

\begin{tabular}{|l|c|c|}
\hline \multicolumn{1}{|c|}{ Curva } & Minimum & Maximum \\
\hline Oval & 3,5 & 12,9 \\
\hline Ellipse obtained by varying the semi axis, $\mathrm{a}+\mathrm{i}, \mathrm{b}+\mathrm{j}$ & 12,5 & 20 \\
\hline Ellipse obtained with least squares method & 13 & 23 \\
\hline Ellipse with axes a and b obtained from the data & 16 & 30 \\
\hline
\end{tabular}

Fig. 8 Comparative table of the maximum separation in the different forms proposed

A summary of these data is shown in Fig. 8, where the maximum separation of the data in each horizontal plane is indicated with the four hypothetical forms we have deduced: the oval, the ellipse with the semi-axis $a$ and $b$ obtained directly from the data, the ellipse obtained with the least squares method and the one that improves these distances obtained by varying the axes as described previously. It is verified that the form that best approximates the data is the one of the oval. Specifically, the ellipse obtained that best approaches them contains points at more than $12.5 \mathrm{~cm}$ in all the planes and that is precisely the greater distance that is obtained when compared to the oval.

All the data obtained reinforce the hypothesis that the construction of the dome was not realized by means of ellipses, but by means of ovals. The dome, therefore, is not an ellipsoid.

\section{References}

1. Arphe i Villafañe, Juan de. 1585. Tratado De varia conmmensuracion para la Escultura y Architectura. Sevilla: imprenta de Andrea Pescioni i Juan de León. 
2. Barrallo J. 2011. Ovals and Ellipses in Architecture. Proceedings of ISAMA 2011, Columbia College, Chicago, Illinois; p. 9-18.

3. Bérchez Gómez, J. 1995. Basílica de Nuestra Señora de los Desamparados (Valencia). In: Monumentos de la Comunidad Valenciana. Catálogo de Monumentos declarados y conjuntos históricos incoados. Tomo X. Valencia. Arquitectura Religiosa. Valencia: Conselleria de Cultura, Educació i Ciència - Generalitat Valenciana, 204-217.

4. Borngässer, B. 1997a. Arquitectura barroca en España y Portugal. In Toman R. (ed.) El barroco. Arquitectura-escultura-pintura. Köln: Könemann, 78-119.

5. Borngässer, B. 1997b. Arquitectura barroca en Francia. In Toman R. (ed.) El barroco. Arquitectura-escultura-pintura. Köln: Könemann, 122-151.

6. Bosch Reig, I., Roig Picazo, P. 1999. El proyecto de restauración arquitectónica de las cúpulas, tambor y linterna de la Basílica de la Virgen de los Desamparados de Valencia. In: Restauración de Pintura Mural aplicada a la Basílica de la Virgen de los Desamparados de Valencia, Roig Picazo, P. y Bosch Reig, I. Valencia: Servicio de Publicaciones de la U.P.V., 21-74.

7. Calvo López, J., Alonso Rodríguez, M.A., Rabasa Díaz, E.; López Mozo, A. 2005. Cantería Renacentista en la Catedral de Murcia. Murcia: Colegio Oficial de Arquitectos.

8. Capilla Tamborero E., Calvo Roselló, V. 2014. Chapter 8: La cúpula interior de la Basílica de la Virgen de los Desamparados de Valencia. Análisis geométrico y matemático. In: J. C. Navarro (ed.) Bóvedas Valencianas. Arquitecturas ideales, reales y virtuales en época medieval y moderna. Valencia: ed. UPV (Scientia), 196-237. ISBN: 978-84-9048-188-2.

9. Connors, J. 1999. Un teorema sacro: San Carlo alle Quattro Fontane. In Il giovane Borromini. Dagli esordi a San Carlo alle Quattro Fontane. Milano: Skira, 459-512.

10. Dotto, E. 2001. Note sulle costruzioni degli ovali a quattro centri. Vecchie e nuove costruzioni dellovale. Disegnare Idee Immagini; XII 23: 714 .

11. Duvernoy, Sylvie. 2015. Baroque Oval Churches: Innovative Geometrical Patterns in Early Modern Sacred Architecture. Nexus Network Journal 17 (2): 425456.

12. Fernández Gómez M. 1996. La planta oval. Traza y símbolo. Loggia. Arquitectura \& Restauración 3: 16-21.

13. García Jara F. 2008. Las cúpulas de la arquitectura religiosa de la provincia de Alicante: del Renacimiento al siglo XIX. Ph.D. Thesis.

14. García Jara F. 2010. La estereotomía de las cúpulas sobre base oval. In: X Congreso Internacional de Expresión Gráfica aplicada a la Edificación, APEGA 2010, Alicante: 767780 .

15. Gentil Baldrich, J. M. 1994. Planta oval y traza elíptica en la arquitectura: Consideraciones geométricas y un ejemplo español. Valladolid.

16. Gentil Baldrich J.M. 1996. La traza oval y la Sala Capitular de la catedral de Sevilla Una aproximación geométrica. In: J. A. Ruiz de la Rosa et al. Quatro edificios sevillanos. Sevilla: Colegio Oficial de Arquitectos de Andalucía, Demarcación Occidental, 73-147.

17. Gómez-Collado, M.C.; Calvo Roselló, V; Capilla Tamborero, E. 2018. Mathematical modeling of oval arches. A study of the George V and Neuilly Bridges. Journal of Cultural Heritage Vol. 32: 144-155; https://doi.org/10.1016/j.culher.2018.01.012

18. Hatch, John G. 2015. The Science Behind Francesco Borrominis Divine Geometry. In: Architecture and Mathematics from Antiquity to the Future, eds. Kim Williams and Michael J. Oswald, vol. II, ch. 61, 217228. Basel: Birkhäuser.

19. Hill, Michael. 2013. Practical and Symbolic Geometry in Borrominis San Carlo alle Quattro Fontane. Journal of the Society of Architectural Historians 72 (4): 555583.

20. Huerta Fernández, S. 2002. Informe sobre la estabilidad de la cúpula interior de la Basílica de la Virgen de los Desamparados de Valencia. Valencia. Conselleria Cultura, Educació y Ciència de la Generalitat Valenciana, 20 páginas.

21. Huerta, S. 2007. Oval domes, geometry and mechanics. Nexus Network Journal 9(2), 211248 .

22. Huerta Fernández, S. 2012. Análisis estructural de cúpulas tabicadas: la cúpula interior de la Basílica de la Virgen de los Desamparados en Valencia. Construyendo Bóvedas Tabicadas. In: Actas del Simposio Internacional sobre bóvedas tabicadas. Valencia, 26 y 27 de mayo de 2011. Valencia: Editorial Universitat Politècnica de València, 318-335.

23. Jung, W. 1997.) Arquitectura y ciudad en Italia. In Toman R. (ed.) El barroco. Arquitectura-escultura-pintura. Köln: Könemann, 12-75. 
24. Kluckert, E. 1997. Arquitectura barroca en Alemania, Suiza, Austria y Europa oriental. In Toman R. (ed.) El barroco. Arquitectura-escultura-pintura. Köln: Könemann, 184-273. 25. López Manzanares, G. 2005. La contribución de R. G. Boscovich al desarrollo de la teoría de cúpulas: el informe sobre la Biblioteca Cesarea de Viena. In: Huerta, S. (ed.) Actas del Cuarto Congreso Nacional de Historia de la Construcción. Cádiz, 27-29 January 2005. Madrid: Instituto Juan de Herrera, 655-665.

26. López Mozo A. 2011. Ovals for Any Given Proportion in Architecture: A Layout Possibly Known in the Sixteenth Century. Nexus Network Journal Vol. 13: 569-597.

27. Mazzotti, A. 2014a. A Euclidean Approach to Eggs and Polycentric Curves. Nexus Network Journal, 16, 345387. DOI 10.1007/s00004-014-0189-5

28. Mazzotti, A. 2014b. What Borromini Might Have Known About Ovals. Ruler and Compass Constructions. Nexus Network Journal. doi:10.1007/s00004-014-0190-z.

29. Mazzotti, A. 2017. All sides to an oval. Properties, Parameters, and Borrominis Mysterious Construction. Springer. DOI 10.1007/978-3-319-39375-9

30. Montoliu Soler, V. 2012. La Real Capilla de la Virgen de los Desamparados de Valencia: sus orígenes histórico-artísticos. Valencia: Real Academia de Cultura Valenciana.

31. Navascués Palacio, P. 1974. El libro de arquitectura de Hernán Ruiz el Joven. Estudio y edición crítica por Pedro Navascues Palacio. Madrid: Escuela Técnica Superior de Arquitectura.

32. Petrovic, Maja et al. 2019. A Focal Curve Approximation of a Borromini Oval Contour. Nexus Network Journal 21:1931 https://doi.org/10.1007/s00004-018-00421-4

33. Ragazzo, F. 1995, Geometria delle figure ovoidali, In Disegnare: 11, 17-24.

34. Rosin P. 2001. On Serlio's construction of ovals. The Mathematical Intelligencer 23(1): 58-69.

35. Serlio S. 1552. Tercero y cuarto libro de Architectura de Sebastiano Serlio Boloñes. Translated by Francisco de Villalpando Architecto. Toledo: Casa de Iván de Ayala, 1552. (Edición facs. Barcelona: Serie Arte y Arquitectura, Editorial Alta Fulla, 1990.) (Edición digitalizada en Huerta, S. 2004. Selección de Tratados españoles de Arquitectura y Construcción de los siglos XVI al XX).

36. Simona, M. 2005. Ovals in Borrominis Geometry. In: Emmer, M., (ed.) Mathematics and Culture II. Visual Perfection: Mathematics and Creativity. Springer. 45-52. springeronline.com

37. Soler Verdú, R. 1995. La cúpula en la arquitectura moderna valenciana. Siglos XVI a XVIII. Metodologías de estudios previos, para las arquitecturas de sistemas abovedados. Ph.D. Thesis. Universitat Politècnica de València.

38. VV.AA. 2001. Real Basílica de la Virgen de los Desamparados de Valencia. Restauración de los fondos pictóricos y escultóricos. 1998-2001. I. Bosch (ed.) Valencia: Fundación para la Restauración de la Basílica de la Mare de Déu dels Desamparats. 